\title{
Fungal Fermented Protein (FFP) : Alternative Ingredient to be Used in Muscovy Duck Diets
}

\author{
Usaneeporn Soipeth $^{1}$, Saowanit Tongpim², Vichai Leelavatcharamas ${ }^{3,4}$, Terdsak Khammeng ${ }^{{ }^{*}}$
}

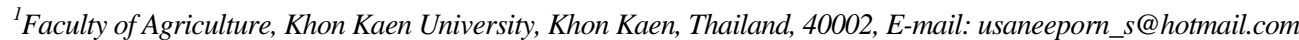

${ }^{2}$ Faculty of Science, Khon Kaen University, Khon Kaen 40002, Thailand

${ }^{3}$ Faculty of Technology, Khon Kaen University, Khon Kaen 40002, Thailand

${ }^{4}$ Fermentation Research Center for Value Added Agricultural Products, 40000, Thailand

\section{A R T I C L E I N F O}

Article history:

Received 05 October 2015

Accepted 29 December 2015

Available online, ISSN: 2148-127X

\section{Keywords:}

Fungal Fermented Protein (FFP)

Growth performance

Muscovy duck

Alternative ingredient

Feedstuff \begin{abstract}
A B S T R A C T
Fungal fermented protein (FFP) was the alternative feedstuff from Aspergillus niger and can be an interesting choice in poultry diets because these product was containing 20.49 $\%$ of crude protein and high leucine $(0.58 \%)$, phenylalanine $(0.58 \%)$ and lysine $(0.38 \%)$ and contained no aflatoxin. The experiments were performed using a completely randomized design with 6 treatments and 3 replications employing eight 1-day-old, mixed sex muscovy ducks (Cairina moschata) per experimental unit. The control birds were fed with a basal diet whereas the test birds were fed with FFP at 5, 10, 15, 20 and $25 \%$ of diet. Feed and water were provided ad libitum. The feed intake of the starter showed no significant difference while the grower and finisher had higher feed intake with higher levels of FFP. In contrast, the high level of FFP yielded the lower final body weight and body weight gain, resulting in the high feed conversion ratio (4.38). For the performance of overall period, the ducks fed with $20 \%$ FFP had higher average daily gain $(29.40$ $\mathrm{g} / \mathrm{b} / \mathrm{d})$, body weight gain $(2,471 \mathrm{~g} / \mathrm{b})$ and feed conversion ratio (3.63). No deaths were found in any pens and the ducks remained in good health.
\end{abstract}

*Corresponding Author:

E-mail: terkha@kku.ac.th

\section{Introduction}

The high cost and scarcity of conventional feed ingredients constitute major problems facing commercial poultry production in the developing countries around the world. In Thailand, soybean meal and fish meal are the most common protein sources used for poultry; and they usually constitute $40 \%-60 \%$ of industrially formulated poultry diets (Apata, 2011). The high cost of soybean meal and fish meal are due to the competition between man and farm animals for grains, and the seasonal production. Many unconventional tropical feed resources, especially agro-industrial wastes, which have potential to be used as poultry feed, could be exploited to reduce the cost and dependence on soybean meal and fish meal.

One of the potential alternative protein sources for poultry feed is the Dried Distillers Cassava with Solubles (DDCS) from ethanol industry. The annual production of ethanol in Thailand is 150,000-200,000 liters/day yielding 30-40 tons/day of ethanol waste by-product. The DDCS had $90.65 \%$ dry matter and low crude protein $(4.65 \%)$ but high crude fiber $(21.98 \%$ ) (Soipeth et al., 2013). This by-product offers an opportunity for cost savings in animal feed rations, and will be available in abundant quantities in coming years. In order to use DDCS for livestock feeding, the physical, chemical and biological factors of DDCS should be considered in formulating feed. Solid-state fermentation (SSF) has been defined as the fermentation process which involves solid material and is carried out in absence or near absence of free water; however, the substrate had enough moisture to support growth and metabolism of the microorganisms (Pandey et al., 2000). The low moisture content means that although SSF is non-septic fermentation, spoilage or contamination by unwanted bacteria is reduced by the low water activity (Aw). The DDCS can be used as substrates in SSF process and its high-fiber materials were broken down by the action of microorganisms, particularly fungi (Graminha et al., 2008).

Hence, this study focused on employing a cellulase and amylase producing Aspergillus niger strain TISTR 3056 in producing fungal fermented protein by DDCS as a substrate. FFP was also evaluated for its effect on the growth performance of muscovy ducks and its potential as nutritional feedstuff. 


\section{Materials and Methods}

Preparation of Fungal Fermented Protein

Aspergillus niger TISTR 3056 was selected for this study based on its cellulase and amylase production (Soipeth et al., 2013; Soipeth, 2007). For a plastic box fermentor, 2,500 $\mathrm{g}$ of DDCS (dried in oven at $60^{\circ} \mathrm{C}$ and grinded mechanically with electric grinder to make in particle form to 4 meshes, sterilized at $121^{\circ} \mathrm{C}$ for 15 minutes) was in oculated in cleanroom and temperature control at $28^{\circ} \mathrm{C}$ with $25 \mathrm{ml}$ of $A$. niger spore suspension $\left(1 \times 10^{8}\right.$ spores $\left./ \mathrm{ml}\right)$ supplemented with $2,020 \mathrm{ml}$ culture medium $\left(\mathrm{KH}_{2} \mathrm{PO}_{4} 17.8 \mathrm{~g}, \mathrm{MgSO}_{4} .7 \mathrm{H}_{2} \mathrm{O} 9.5 \mathrm{~g}\right.$, citric acid $27.4 \mathrm{~g}$, urea $70 \mathrm{~g}$ distilled water $1,000 \mathrm{ml}$ and adjusted $\mathrm{pH} 5)$. The initial $\mathrm{pH}$ was 5 and the initial moisture was $60 \%$ (Figure 1). After fermentation period (7 days), the FFP sample was collected for proximate analysis; soluble protein content was measured by using the folin method (Lowry et al., 1951) and amino acid compositions were analyzed using an AOAC official method 994.12, 988.15 (2000) by GC-MS; Oven $100^{\circ} \mathrm{C}$ hold $2 \mathrm{~min}, 10^{\circ} \mathrm{C} / \mathrm{min}$ to $300^{\circ} \mathrm{C}$ hold $3 \mathrm{~min}$ and $\mathrm{He}$ carrier gas flow $1.0 \mathrm{~mL} / \mathrm{min}$ Column HP 5MS Agilent technologies made in USA. $0.25 \mathrm{~mm} \times 30 \mathrm{~m} \times 0.25$ micron of film (Model $6890 \mathrm{~N}$, Germany). Agilent technologies Model 5973 inert, USA; Scan $30-300 \mathrm{~m} / \mathrm{z}$, MS Quadrupole temperature $150^{\circ} \mathrm{C}$ and MS Source temperature $230^{\circ} \mathrm{C}$ ). Aflatoxin measurement by HPLC according to the in-house method based on AOAC (acetonitrile and methanol, used for the mobile phase, Whatman filter paper (qualitative, 1) and a $0.45 \mu \mathrm{m}$ were used for filtration.

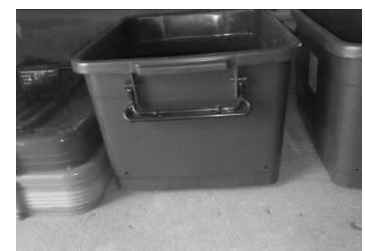

(a)

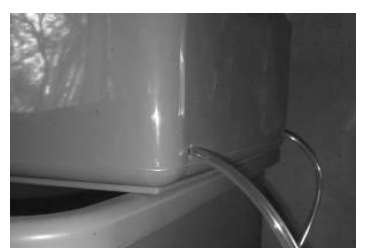

(b)

Animals and Experimental Design

Total mixed sex of 144 muscovy ducks at the age of 1-day-old were obtained from Tha-pra Livestock Research and Breeding Center, Khon Kaen Province, Thailand. The experiment was used completely randomized design by 6 treatments and 3 replications. The ducklings were weighed and allocated to each of 18 pens in an enclosed house. Lighting was continuous. Litter were rice husks and an electric border in each pen provided heat at the appropriate temperature for 14 days to ducklings confined to a small area. The control birds were fed a basal diet, and the treatment fed with FFP 5, $10,15,20$ and $25 \%$ of diet (Table 1-3). All diets were formulated to exceed the minimum nutrient requirements recommended by NRC (1994). Feed and water were given ad libitum for 84 days. Chemical compositions of diets were analyzed by proximate analysis (AOAC, 1984).

\section{Statistical Analysis}

The data from the feeding trial as daily feed intake (DFI), body weight gain (BWG), feed conversion ratio (FCR) and average daily gain (ADG) were subjected to one-way analysis of variance, and multiple comparisons among means were made by Duncan's multiple range tests using the SAS version 9.1 computer programs (SAS, 2008). All statements of differences were based on significance at $\mathrm{P}<0.05$.

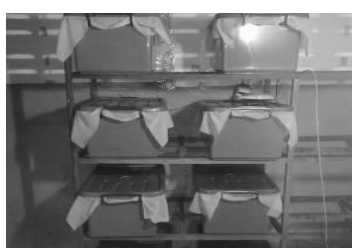

(c)

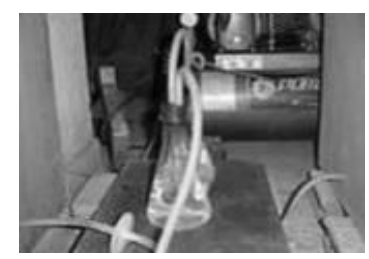

(d)

Figure 1 (a) Plastic box of $30 \times 40 \times 30 \mathrm{~cm}$. (b) Bottom of the box was connected to a filtered air supply with rubber tube of $0.5 \mathrm{~cm}$ diameter. (c) The box was incubated in clean room. (d) Air flow was sterilized by passing through a 0.45 $\mu \mathrm{m}$ cellulose filter with air pump.

Table 1 Composition of experimental diets for muscovy duckling $(0-2 \mathrm{wk})$

\begin{tabular}{|c|c|c|c|c|c|c|}
\hline \multirow{2}{*}{ Ingredient (\%) } & \multicolumn{6}{|c|}{ Level of FFP (\%) } \\
\hline & 0 & 5 & 10 & 15 & 20 & 25 \\
\hline Yellow Corn & 44.5 & 41.4 & 38.45 & 35.53 & 32.25 & 29.35 \\
\hline Soybean meal $44 \%$ & 38.0 & 36.2 & 34.35 & 32.42 & 30.7 & 28.8 \\
\hline FFP & 0 & 5 & 10 & 15 & 20 & 25 \\
\hline Rice bran & 9 & 9 & 9 & 9 & 9 & 9 \\
\hline Fish meal $55 \%$ & 2 & 2 & 2 & 2 & 2 & 2 \\
\hline DCP (P18\%) & 0.85 & 0.85 & 0.85 & 0.85 & 0.85 & 0.85 \\
\hline Limestone & 0.5 & 0.5 & 0.5 & 0.5 & 0.5 & 0.5 \\
\hline Palm oil & 3.25 & 3.2 & 3.05 & 2.9 & 2.9 & 2.7 \\
\hline Sodium chloride & 0.2 & 0.2 & 0.2 & 0.2 & 0.2 & 0.2 \\
\hline L-Lysine & 0.6 & 0.6 & 0.6 & 0.6 & 0.6 & 0.6 \\
\hline Premix $^{1}$ & 1 & 1 & 1 & 1 & 1 & 1 \\
\hline Total (kg) & 100 & 100 & 100 & 100 & 100 & 100 \\
\hline Total cost (USD/kg) & 0.51 & 0.48 & 0.45 & 0.42 & 0.40 & 0.40 \\
\hline
\end{tabular}

${ }^{\mathrm{T}}$ Mineral and vitamin premix (content per 100 kilograms of diet): $\mathrm{MnO} 60 \%, 1.333 \mathrm{~g} ; \mathrm{ZnO} 72 \%, 4.861 \mathrm{~g} ; \mathrm{Na}_{2} \mathrm{SeO}{ }_{3} 45 \%, 0.022 \mathrm{~g} ; \mathrm{MgO} 55 \%, 90.873$ g; vitamin A, 250,000 IU; vitamin $\mathrm{D}_{3}, 40,000 \mathrm{IU}$; vitamin E50, 1,000 IU; vitamin $\mathrm{K}_{3} 51 \%, 0.98$ g; vitamin B2 96\%, 2.188 ; vitamin $\mathrm{B}_{3} 96 \%, 0.521 \mathrm{~g}$; vitamin $\mathrm{B}_{6} 96 \%, 11.229 \mathrm{~g},{ }^{2}$ Price of FFP $=0.14 \mathrm{USD} / \mathrm{kg}$. 
Table 2 Composition of experimental diets for growing muscovy duck (3-7 wk)

\begin{tabular}{l|cccccc}
\hline \multirow{2}{*}{ Ingredient (\%) } & \multicolumn{5}{c}{ Level of FFP (\%) } \\
\cline { 2 - 6 } & 0 & 5 & 10 & 15 & 20 & 25 \\
\hline Yellow Corn & 44.5 & 41.4 & 38.45 & 35.53 & 32.25 & 29.35 \\
Soybean meal 44\% & 38.0 & 36.2 & 34.35 & 32.42 & 30.7 & 28.8 \\
FFP & 0 & 5 & 10 & 15 & 20 & 25 \\
Rice bran & 9 & 9 & 9 & 9 & 9 & 9 \\
Fish meal 55\% & 2 & 2 & 2 & 2 & 2 & 2 \\
DCP (P18\%) & 0.85 & 0.85 & 0.85 & 0.85 & 0.85 & 0.85 \\
Limestone & 0.5 & 0.5 & 0.5 & 0.5 & 0.5 & 0.5 \\
Palm oil & 3.25 & 3.2 & 3.05 & 2.9 & 2.9 & 2.7 \\
Sodium chloride & 0.2 & 0.2 & 0.2 & 0.2 & 0.2 & 0.2 \\
L-Lysine & 0.6 & 0.6 & 0.6 & 0.6 & 0.6 & 0.6 \\
Premix & 1 & 1 & 1 & 1 & 1 & 1 \\
Total (kg) & 100 & 100 & 100 & 100 & 100 & 100 \\
Total cost (USD/kg) & 0.51 & 0.48 & 0.45 & 0.45 & 0.40 & 0.40 \\
\hline
\end{tabular}

${ }^{1}$ Mineral and vitamin premix (content per 100 kilograms of diet): $\mathrm{MnO} 60 \%, 1.333 \mathrm{~g} ; \mathrm{ZnO} 72 \%, 4.861 \mathrm{~g} ; \mathrm{Na}_{2} \mathrm{SeO}_{3} 45 \%, 0.022 \mathrm{~g} ; \mathrm{MgO} 55 \%, 90.873$ g; vitamin A, 250,000 IU; vitamin $\mathrm{D}_{3}, 40,000 \mathrm{IU}$; vitamin E50, 1,000 IU; vitamin $\mathrm{K}_{3}$ 51\%, $0.98 \mathrm{~g}$; vitamin $\mathrm{B} 2$ 96\%, 2.188; vitamin $\mathrm{B}_{3}$ 96\%, 0.521 g; vitamin $\mathrm{B}_{6} 96 \%, 11.229 \mathrm{~g},{ }^{2}$ Price of $\mathrm{FFP}=0.14 \mathrm{USD} / \mathrm{kg}$.

Table 3 Composition of experimental diets for finishing muscovy duck (8-12 wk)

\begin{tabular}{|c|c|c|c|c|c|c|}
\hline \multirow{2}{*}{ Ingredient (\%) } & \multicolumn{6}{|c|}{ Level of FFP $(\%)$} \\
\hline & 0 & 5 & 10 & 15 & 20 & 25 \\
\hline Yellow Corn & 61.8 & 58.85 & 55.8 & 52.87 & 49.7 & 46.63 \\
\hline Soybean meal $44 \%$ & 20.6 & 18.75 & 16.9 & 15.03 & 13.2 & 11.37 \\
\hline FFP & 0 & 5 & 10 & 15 & 20 & 25 \\
\hline Rice bran & 9 & 9 & 9 & 9 & 9 & 9 \\
\hline Fish meal 55\% & 1 & 1 & 1 & 1 & 1 & 1 \\
\hline DCP (P18\%) & 1.5 & 1.5 & 1.5 & 1.5 & 1.5 & 1.5 \\
\hline Limestone & 1.4 & 1.4 & 1.4 & 1.4 & 1.4 & 1.4 \\
\hline Palm oil & 2.9 & 2.7 & 2.6 & 2.4 & 2.4 & 2.3 \\
\hline Sodium chloride & 0.2 & 0.2 & 0.2 & 0.2 & 0.2 & 0.2 \\
\hline L-Lysine & 0.6 & 0.6 & 0.6 & 0.6 & 0.6 & 0.6 \\
\hline Premix $^{1}$ & 1 & 1 & 1 & 1 & 1 & 1 \\
\hline Total (kg) & 100 & 100 & 100 & 100 & 100 & 100 \\
\hline Total cost (USD/kg) & 0.45 & 0.42 & 0.42 & 0.40 & 0.37 & 0.34 \\
\hline
\end{tabular}

${ }^{1}$ Mineral and vitamin premix (content per 100 kilograms of diet): $\mathrm{MnO} 60 \%, 1.333 \mathrm{~g} ; \mathrm{ZnO} 72 \%, 4.861 \mathrm{~g} ; \mathrm{Na}_{2} \mathrm{SeO}_{3} 45 \%, 0.022 \mathrm{~g} ; \mathrm{MgO} 55 \%, 90.873$ g; vitamin A, 250,000 IU; vitamin $\mathrm{D}_{3}, 40,000 \mathrm{IU}$; vitamin E50, 1,000 IU; vitamin $\mathrm{K}_{3} 51 \%, 0.98 \mathrm{~g}$; vitamin B2 96\%, 2.188; vitamin $\mathrm{B}_{3} 96 \%$, $0.521 \mathrm{~g}$; vitamin $\mathrm{B}_{6} 96 \%, 11.229 \mathrm{~g},{ }^{2}$ Price of FFP $=0.14 \mathrm{USD} / \mathrm{kg}$.

\section{Results and Discussions}

The FFP from plastic box fermentor had $20.49 \%$ of crude protein, dry matter $70.37 \%$, ether extract $0.56 \%$, crude fiber $15.04 \%$, ash $11.28 \%$ and gross energy $3.039 .98 \mathrm{kcal} / \mathrm{kg}$. True protein was $19.86 \%$ (Table 4). The FFP has high leucine, phenylalanine and lysine. No aflatoxin detected. The daily feed intake of the starter showed no significant difference but the grower and finisher had higher feed intake with higher levels of FFP. In contrast, the high level of FFP (25\%) yielded the lower final body weight and body weight gain $(\mathrm{P}<0.05)$, resulting in the highly feed conversion ratio (4.38). According to the performance of overall period, the Muscovy ducks fed with $20 \%$ of FFP had higher average daily gain and body weight gain $(29.40 \mathrm{~g} / \mathrm{b} / \mathrm{d}$ and 2,471 $\mathrm{g} / \mathrm{b})$ and feed conversion ratio was $3.63(\mathrm{P}<0.05)$.

This fungus grew well on the surface of the particle and penetrates through the inter-particle spaces to the depth of the bed. The fungal fermentation performed best at $\mathrm{pH} 5,28-30^{\circ} \mathrm{C}, 60 \%$ initial moisture and inoculum of
$1 \times 10^{8}$ fungal spores $/ \mathrm{ml}$, so FFP was $20.49 \%$ crude protein. FFP had high leucine, phenylalanine and lysine content (Table 5). Lysine content of FFP $(0.38 \%)$ was higher than corn meal $(0.25 \%)$. Any types of aflatoxin were not detected by HPLC (Table 6).

The A. niger TISTR 3056 was selected and used in solid-state fermentation. After fermentation, the crude protein content increased from $9 \%$ to $20.49 \%$, which could be used as protein source in animal rations. Sadaf et al. (2005) reported that majority of Aspergillus sp. and Penicillium sp. was found to have cellulolytic activity. The FDA in the United States has accepted numerous enzymes for food use: in the early 1960s the FDA issued opinion letters recognizing that $\alpha$-amylase, cellulase, amyloglucosidase, catalase, glucose oxidase, lipase and pectinase from A. niger could be 'generally regarded as safe' (GRAS) under the condition that non-pathogenic and non-toxigenic strains and current good manufacturing practices be used in production. These results showed that 
no detection of all types of aflatoxin was found.

The high feed intake with high levels of FFP may have occurred as a result of the flavor compounds produced during SSF which improved the palatability of the fermented meal (Feron et al., 1996). These results were in agreement with those obtained by Wang et al. (2008) who found that at 14 days post hatch of chick, the higher levels of DDGS numerically reduced the body weight at 35, 42 and 49 days, being reduced gradually as DDGS level increased. The improvements in body weight gain of duck fed with the FFP like the enzyme supplement could be ascribed to the increase in nutrient digestibility. The FFP has already fermented and digested crude fiber by amylase and cellulase enzymes. These results supported by Abudabos (2010) who reported that fermented by-products by Trichoderma virideculture were significant increased in body weight gain of broilers.
The result of Odunsei et al. (2002) who found the fermented soybean meal was giving the improvement of protein as $52.04 \%$ and the decreasing crude fiber around $42.03 \%$ of the waste, but still limited to use in poultry ration.

These studies pointed out that the great advantage of SSF process is the extremely cheap raw material used as the main substrate. Therefore, SSF is certainly a good way of utilizing nutrient rich solid waste as a substrate.

There were no deaths in any pens and ducks remained in good health. The effects of experimental treatments on ducks' performance during the whole experimental period (1-84 days) were presented in Table 7. Body weight gain (BWG), average daily gain (ADG) of ducks fed with $20 \%$ of FFP were significantly higher $(\mathrm{P}<0.05)$ and feed conversion ratio (FCR) was significantly lower (3.63) than ducks fed with the other diet.

Table 4 Chemical compositions of FFP by plastic box fermentor

\begin{tabular}{l|ccc}
\hline Nutrients, \% & DDCS & Control substrate & FFP \\
\hline Dry matter, $\mathrm{DM}^{1 /}$ & 90.65 & 60.55 & 90.37 \\
Crude protein, $\mathrm{CP}^{2 /}$ & 4.65 & 9.14 & 20.49 \\
True protein & $2 / *$ & 4.76 & 19.86 \\
Ether extract, $\mathrm{EE}^{2 /}$ & 2.87 & 0.40 & 0.56 \\
Crude fiber, $\mathrm{CF}^{2 /}$ & 0.38 & 21.98 & 15.04 \\
Ash $^{2 /}$ & 21.98 & 28.78 & 11.28 \\
Gross energy, $\mathrm{GE} \mathrm{kcal} / \mathrm{kg}^{2 /}$ & 28.78 & 3008.87 & 3039.98 \\
Calcium, Ca & 3005.69 & 0.54 & 0.66 \\
Phosphorus, $\mathrm{P}^{2 /}$ & - & 0.65 & 0.75 \\
\hline I/ & - & &
\end{tabular}

${ }^{1 /}$ air dry basis (\%), ${ }^{2 /}$ dry matter basis (\%), *Folin method (Lowry et al., 1951)

Table 5 Aflatoxin test by HPLC method

\begin{tabular}{|c|c|c|}
\hline Types of Aflatoxin & Test Results & Level of Detection $(\mu \mathrm{g} / \mathrm{kg})$ \\
\hline B1 & Not detected & 0.05 \\
\hline B2 & Not detected & 0.10 \\
\hline G1 & Not detected & 0.05 \\
\hline $\mathrm{G} 2$ & Not detected & 0.20 \\
\hline Total Aflatoxin & Not detected & \\
\hline
\end{tabular}

Table 6 Amino acid compositions of FFP

\begin{tabular}{l|cc}
\hline Amino acid profiles ${ }^{I /}$ & Units $(\mathrm{mg} / 100 \mathrm{~g})$ & $(\%)$ \\
\hline Alanine & 121.67 & 0.122 \\
Arginine & $<5.00$ & $<0.005$ \\
Aspartic acid & 145.87 & 0.146 \\
Cystine & $<5.00$ & $<0.005$ \\
Glutamic acid & 229.07 & 0.229 \\
Glycine & 98.81 & 0.098 \\
Histidine & 200.80 & 0.200 \\
Hydroxylysine & $<5.00$ & $<0.005$ \\
Isoleucine & 308.64 & 0.309 \\
Leucine & 581.71 & 0.582 \\
Lysine & 379.80 & 0.380 \\
Methionine & 45.31 & 0.045 \\
Phenylalanine & 582.06 & 0.582 \\
Proline & 149.49 & 0.149 \\
Serine & 51.39 & 0.051 \\
Threonine & 45.91 & 0.046 \\
Tryptophan & 40.44 & 0.040 \\
Tyrosine & 325.15 & 0.325 \\
Valine & 208.89 & 0.209 \\
\hline
\end{tabular}


Table 7 Effects of FFP on growth performance of muscovy duck (Thapra 2)

\begin{tabular}{|c|c|c|c|c|c|c|c|}
\hline \multirow{2}{*}{ Parameters } & \multicolumn{6}{|c|}{ Level of FFP (\%) } & \multirow{2}{*}{ SEM } \\
\hline & 0 & 5 & 10 & 15 & 20 & 25 & \\
\hline Initial weight(g) & 43 & 43 & 43 & 43 & 43 & 43 & \\
\hline Final weight (g) & $2400^{\mathrm{b}}$ & $2496^{\mathrm{a}}$ & $2319^{\mathrm{d}}$ & $2377^{\mathrm{c}}$ & $2514^{\mathrm{a}}$ & $2344^{\mathrm{d}}$ & 32.615 \\
\hline $\mathrm{BWG}(\mathrm{g})$ & $2357^{\mathrm{c}}$ & $2453^{\mathrm{b}}$ & $2276^{\mathrm{f}}$ & $2334^{\mathrm{d}}$ & $2471^{\mathrm{a}}$ & $2301^{\mathrm{e}}$ & 32.617 \\
\hline \multicolumn{8}{|c|}{ Daily Feed Intake ; DFI (g/b/d) } \\
\hline $0-2 \mathrm{wk}$ & $14.9^{\mathrm{e}}$ & $15.7^{\mathrm{c}}$ & $14.8^{\mathrm{f}}$ & $15.2^{\mathrm{d}}$ & $16.1^{\mathrm{a}}$ & $16.0^{\mathrm{b}}$ & 0.2330 \\
\hline $3-7$ wk & $109.9^{\mathrm{f}}$ & $110.4^{\mathrm{d}}$ & $110.2^{\mathrm{e}}$ & $113.3^{c}$ & $115.6^{\mathrm{b}}$ & $125.7^{\mathrm{a}}$ & 2.4636 \\
\hline $8-12$ wk & $138.9^{\mathrm{c}}$ & $138.4^{\mathrm{d}}$ & $135.5^{\mathrm{f}}$ & $135.9^{\mathrm{e}}$ & $140.3^{\mathrm{b}}$ & $155.4^{\mathrm{a}}$ & 3.0269 \\
\hline $0-12 \mathrm{wk}$ & $106.1^{\mathrm{c}}$ & $106.9^{\mathrm{b}}$ & $102.5^{\mathrm{e}}$ & $104.2^{\mathrm{d}}$ & $106.8^{\mathrm{b}}$ & $119.9^{\mathrm{a}}$ & 2.5307 \\
\hline \multicolumn{8}{|c|}{ Average Daily Gain; ADG (g/b/d) } \\
\hline $0-2 \mathrm{wk}$ & $6.8^{\mathrm{a}, \mathrm{b}}$ & $7.4^{\mathrm{a}, \mathrm{b}}$ & $6.8^{\mathrm{a}, \mathrm{b}}$ & $6.8^{\mathrm{a}, \mathrm{b}}$ & $6.7^{\mathrm{a}, \mathrm{b}}$ & $5.7^{\mathrm{b}}$ & 0.2185 \\
\hline $3-7$ wk & $26.3^{\mathrm{b}}$ & $29^{\mathrm{a}, \mathrm{b}}$ & $27.9^{\mathrm{b}}$ & $28^{\mathrm{a}, \mathrm{b}}$ & $31.3^{\mathrm{a}}$ & $27.1^{\mathrm{b}}$ & 0.7112 \\
\hline $8-12 \mathrm{wk}$ & 25.8 & 23.6 & 23.8 & 23.9 & 23.8 & 24.3 & 0.3336 \\
\hline $0-12 \mathrm{wk}$ & $28.0^{\mathrm{b}, \mathrm{c}}$ & $29.2^{\mathrm{a}, \mathrm{b}}$ & $27.1^{\mathrm{c}}$ & $27.7^{\mathrm{c}}$ & $29.4^{\mathrm{a}}$ & $27.4^{\mathrm{c}}$ & 0.3896 \\
\hline \multicolumn{8}{|c|}{ Feed Conversion Ratio; FCR } \\
\hline $0-2$ wk & $1.24^{\mathrm{d}}$ & $1.21^{\mathrm{e}}$ & $1.24^{\mathrm{c}, \mathrm{d}}$ & $1.28^{\mathrm{b}, \mathrm{c}}$ & $1.29^{\mathrm{b}}$ & $1.59^{\mathrm{a}}$ & 0.0575 \\
\hline $3-7$ wk & $4.18^{\mathrm{b}}$ & $3.71^{\mathrm{d}}$ & $3.95^{\mathrm{c}}$ & $3.96^{\mathrm{c}}$ & $3.69^{\mathrm{e}}$ & $4.63^{\mathrm{a}}$ & 0.1427 \\
\hline $8-12 \mathrm{wk}$ & $5.37^{\mathrm{d}}$ & $5.85^{\mathrm{b}}$ & $5.68^{\mathrm{c}}$ & $5.68^{\mathrm{c}}$ & $5.88^{\mathrm{b}}$ & $6.38^{\mathrm{a}}$ & 0.1364 \\
\hline $0-12$ wk & $3.78^{\mathrm{b}}$ & $3.66^{\mathrm{d}}$ & $3.78^{\mathrm{b}}$ & $3.75^{\mathrm{c}}$ & $3.63^{\mathrm{e}}$ & $4.38^{\mathrm{a}}$ & 0.1129 \\
\hline Survival (\%) & 100 & 100 & 100 & 100 & 100 & 100 & \\
\hline
\end{tabular}

Note: ${ }^{\mathrm{a}, \mathrm{b}, \mathrm{c}, \mathrm{d}, \mathrm{e}, \mathrm{f}}$ Values within a row with different superscripts differ significantly at $\mathrm{P}<0.05$

\section{Conclusions}

FFP was the alternative feedstuff and can be an interesting choice in poultry diets because FFP was containing $20.49 \%$ of crude protein and high leucine $(0.58 \%)$, phenylalanine $(0.58 \%)$ and lysine $(0.38 \%)$. FFP was safe from all types of aflatoxin and can be used in the feed of muscovy ducks without affecting on growth performance. This suggested that the use of up to $20 \%$ FFP did not adversely affect the palatability of the feed for the ducks. The increasing levels of protein on DDCS and/ or waste from agricultural industries obtained from the plastic box fermentor could be developed by the optimal growth conditions of A. niger. Moreover, the major raw material with high fiber as a carbon source for the fungus and the quality control of production without toxic metabolizes could be a constant protein source and could be used as feedstuffs.

The increased use of alternative ingredients has increased the demand for microbial enzyme supplements. The results of a series of studies recently completed or ongoing researches suggest that the nutritive value of such ingredients can be improved through supplementation with microbial and fermentation method. As it is likely that such FFP.

\section{Acknowledgements}

The authors would like to thanks Thai Nguan Ethanol CO., LTD for DDCS. Thanks to Fermentation Research Center for Value Added Agricultural Products (FerVAAP), Khon Kaen University for laboratory and thanks to Office of Research Administration and Graduate School, Khon Kaen University for parts of the financial support of this research.

\section{References}

Abudabos A. 2010. Enzyme supplementation of corn-soybean meal diets improves performance in broiler chicken. Int. J. Poult. Sci. 9, 292-297.

Apata DF. 2011. Effect of Terminalia catappa fruit meal fermented by Aspergillus niger as replacement of maize on growth performance, nutrient digestibility, and serum biochemical profile of broiler chickens. Biotechnol. Res.Int. Available from http://dx.doi.org/10.4061/2011/907546.

AOAC. 1984. Official methods of Analysis. $14^{\text {th }}$ Edn., A.O.A.C. Arlington, VA.

Feron G, Bonnarme P, Durand A. 1996. Prospects for the microbial production of food flavours. Food. Sci. Technol. 7, 285-293.

Graminha EBN, Gonc AZL, Alves RDPB, Pirota MAA, Balsalobre RDS, Gomes E. 2008. Enzyme production by solid-state fermentation: application to animal nutrition. Anim. Feed. Sci. Technol. 1-22.

Lowry OH, Rosebrough NJ, Farr AL, Randall RJ. 1951. Protein measurement with the folin phenol reagent. J. Biol. Chemist. 265-275.

NRC. 1994. Nutrient requirements of poultry. $9^{\text {th }}$ Rev. Ed. National Academy Press, Washington, DC, USA.

Odunsei AA, Akande TO, Yusup AS, Salam RJ. 2002. Comparative utilization high inclusion rate of four agro industrial by products in the diet of egg type chickens. Arch. zootech. 465-468.

Pandey A, Soccol C, Mitchell D. 2000. New developments in solid state fermentation: I-bioprocesses and products. Proc. Biochemist. 1153-1169.

Sadaf J, Nazia K, Saman J, Muhammad S, Saleem S, Aqeel A, Shakeel AK. 2005. Screening and characterization of fungal cellulases isolated from the native environmental source. Pakistan. J. Botany. 37, 739-748.

SAS Institute Inc. 2008. User Installation Guide for SAS 9.1.3 Foundation for Microsoft Windows. Cary, NC, USA.

Soipeth, U. 2007. Effects of protein-enriched and phytase cassava from Aspergillus niger on commercial duck rations. Master of Science Thesis in Animal Science, Graduate School, Khon Kaen University, Khon Kaen, Thailand.

Soipeth U, Tongpim S, Leelavatcharamas V, Khammeng T. 2013. Screening of cellulase- and amylase- producing fungi to fermenting the agro-industrial waste for using as feedstuffs. Proceeding of $14^{\text {th }}$ Graduate Research Conference, Khon Kaen University, pp 57-64.

Wang Z, Cerrate S, Coto C, Yan F, Waldroup PW. 2008. Evaluation of high levels of distillers dried grains with solubles (DDGS) in broiler diet. Int. J. Poult. Sci.7, 990-996. 